\title{
Diversity and Physiological Characteristics of Culturable Bacteria from Marine Sediments of Ross Sea, Antarctica
}

\author{
Yung Mi Lee ${ }^{1,2 *}$, You-Jung Jung ${ }^{1}$, Soon Gyu Hong ${ }^{1}$, Ji Hee Kim ${ }^{1}$, and Hong Kum Lee ${ }^{1}$ \\ ${ }^{1}$ Division of Polar Life Sciences, Korea Polar Research Institute, Incheon 406-840, Republic of Korea \\ ${ }^{2}$ School of Biological Sciences, College of Natural Science, Seoul National University, Seoul 151-847, Republic of Korea
}

\section{남극 로스해 퇴적물로부터 분리된 세균의 다양성 및 생리학적 특성}

\author{
이영미 ${ }^{1,2 *} \cdot$ 정유정 $^{1} \cdot$ 홍순규 $^{1} \cdot$ 김지희 ${ }^{1} \cdot$ 이홍금 ${ }^{1}$ \\ ${ }^{1}$ 극지연구소 극지생명과학연구부, ${ }^{2}$ 서울대학교 생명과학대학
}

(Received March 14, 2014 / Accepted April 2, 2014)

\begin{abstract}
The affiliations and physiological characteristics of culturable bacteria isolated from the sediments of Ross Sea, Antarctica were investigated. Sixty-three isolates obtained by cultivation were grouped into 21 phylotypes affiliated with the phyla Actinobacteria and Bacteroidetes and with the classes Alphaproteobacteria and Gammaproteobacteria by phylogenetic analysis of $16 \mathrm{~S}$ rRNA gene sequences. Based on phylogenetic analysis $(<98.65 \%$ sequence similarity), approximately $49 \%$ of total isolates represented potentially novel species or genus. Among them, extracellular protease, lipase, and exopolysaccharide activities at $10{ }^{\circ} \mathrm{C}$ or $20^{\circ} \mathrm{C}$ were detected in approximately $46 \%$, $\mathbf{2 5 \%}$, and $32 \%$ of the strains, respectively. Forty-three isolates produced at least one type of extracellular material and 21 of them produced at least two extracellular protease, lipase, and/or exopolysaccharides. Our findings indicate that culturable bacterial diversity present within the marine sediments of Ross Sea, Antarctica may contribute to the hydrolysis of the major organic constituents which is closely related with carbon and nitrogen cycling in this environment.
\end{abstract}

Keywords: cold-active enzymes, cultivation, exopolysaccharides, marine sediments

The fraction of benthic bacteria may account for $10 \%$ to $30 \%$ of the Earth's total biomass and approximately $70 \%$ of the global prokaryotic biomass (Whitman et al., 1998; Li et al., 2009). In addition, benthic bacterial communities in the ocean play significant roles in biogeochemical cycles and in the remineralization of organic materials (Ravenschlag et al., 2001; Li et al., 2009).

Among the diverse mechanisms that enable microorganisms to survive and thrive in cold environments are adaptive alterations in cellular proteins and lipids (Russell, 1998; Gerday et al., 2000). In polar environments, extracellular enzymes secreted by cold-adapted microorganisms play a crucial ecological role in nutrient cycling (Staley and Herwig, 1993; Vazquez et al., 2004). These cold-active enzymes are also highly valuable because of their potential biotechnological applications that reduce the energy required for chemical

*For correspondence. E-mail: ymlee@kopri.re.kr; Tel.: +82-32-7605581; Fax: +82-32-760-5597 processes (Groudieva et al., 2004) and the potential use of exopolysaccharides from polar fungi and bacteria as cryoprotectants (Selbmann et al., 2002; Kim and Yim, 2007). Thus, the ability of the newly isolated psychrophilic or psychrotolerant strains to produce a broad spectrum of cold-active enzymes and other materials is of great interest for both fundamental research and a broad range of industrial, agricultural, and medical applications (Yu et al., 2011).

New molecular techniques have enabled cultivationindependent approaches to be widely adopted in research into microbial diversity (Bai et al., 2006). Nonetheless, previous studies on benthic bacterial communities by culture-independent methods revealed that many of the OTUs detected had low similarities with known strains, indicating their unknown functions and physiologies (Bowman and McCuaig, 2003; Polymenakou et al., 2005; Webster et al., 2006). This observation highlighted the necessity for cultivation, to isolate previously undescribed strains and to understand their physiological characteristics. Determination of the physiological characteristics 
120 Lee et al.

Table 1. Sampling sites and sample collection information.

\begin{tabular}{clccc}
\hline Sample ID & \multicolumn{1}{c}{ Sampling site } & Water depth $(\mathrm{m})$ & Sampling method & Sampling date \\
\hline Sed 1 & $74^{\circ} 38^{\prime} 46.20^{\prime \prime} \mathrm{S} / 164^{\circ} 13^{\prime} 24.60^{\prime \prime} \mathrm{E}$ & 156 & Box corer & $2011-02-06$ \\
Sed2 & $76^{\circ} 06^{\prime} 17.10^{\prime \prime} \mathrm{S} / 169^{\circ} 12^{\prime} 45.36^{\prime \prime} \mathrm{-}-76^{\circ} 41^{\prime} 03.60^{\prime \prime} \mathrm{S} / 169^{\circ} 11^{\prime} 30.66^{\prime \prime} \mathrm{E}$ & 375 & Dredge & $2011-02-08$ \\
Sed3 & $74^{\circ} 37^{\prime} 30.61^{\prime \prime} \mathrm{S} / 164^{\circ} 14^{\prime} 56^{\prime \prime} \mathrm{E}$ & 54 & Grab sampler & $2011-02-11$ \\
\hline
\end{tabular}

of culturable microorganisms can provide information on their ecological roles of at least some members of the microbial community (Jiang et al., 2006). In addition, the culture-based approach is appropriate for assembling a collection of microorganisms for biochemical, genetic, and physiological studies (Jiang et al., 2006).

In this study, we present the taxonomic affiliations of bacterial isolates recovered from the sediments of Ross Sea, Antarctica to gain insights into the nature of the culturable bacterial diversity. Additionally, the physiological characteristics of the obtained bacteria were investigated.

\section{Materials and Methods}

\section{Samples and isolation of bacterial strains}

Marine sediments were collected in 2011 from three sites in Ross Sea, Antarctica by a box corer, dredge, or grab sampler (Table 1). The samples were suspended in $20 \%$ glycerol and preserved at $-80^{\circ} \mathrm{C}$ until use. For cultivation of bacterial isolates, the samples were serially diluted up to $10^{-3}$ in sterilized sea water and $100-\mu 1$ aliquots of the diluted sample suspensions were spread on four kinds of medium followed by incubation at $10^{\circ} \mathrm{C}$ for $12-22$ days. The media used in these cultivations were: (1) marine agar (MA, Difco, USA), (2) 1/10 diluted marine agar (0.1× MA), (3) marine R2A (MR2A, Difco), and (4) $1 / 10$ diluted marine R2A ( $0.1 \times$ MR2A). After incubation, colonies from the agar plates were picked on the basis of their morphology and subcultured in fresh agar medium until pure isolates were obtained. Pure cultures of the bacterial isolates were deposited in the Polar and Alpine Microbial Collection (PAMC) (Lee et al., 2012).

\section{Examination of physiological characteristics}

Cell suspensions cultured in marine broth medium (Difco) at $10^{\circ} \mathrm{C}$ with shaking at $120 \mathrm{rpm}$ were used to investigate the physiological characteristics of the respective isolates. Growth temperature and the production of extracellular protease, lipase, and exopolysaccharides were determined using the replica plating methods of Lee et al. (2012). The temperature-dependent growth response was studied by replica plating of cell suspensions with a 96-pin replicator (VP-408B, V\&P Scientific, USA) followed by a 7 -day incubation at $4{ }^{\circ} \mathrm{C}, 10^{\circ} \mathrm{C}, 15^{\circ} \mathrm{C}, 20^{\circ} \mathrm{C}$, $25^{\circ} \mathrm{C}, 30^{\circ} \mathrm{C}$, or $37^{\circ} \mathrm{C}$. Growth was evaluated by scoring the size and turbidity of the colony, as described by Lee et al. (2012). Protease and lipase secretion was examined by replica plating of cell suspensions onto $0.1 \times$ MA plates supplemented with $1 \%$ skim milk (Difco) or $1 \%$ tributyrate (Sigma, USA), respectively. The plates were incubated for 7 days at $10^{\circ} \mathrm{C}$ and $20^{\circ} \mathrm{C}$, respectively. Enzyme secretion was scored based on the ratio of colony size to the width of the clear zone surrounding the colony. Exopolysaccharide (EPS) production was recognized by the formation of ropy colonies (Macura and Townsley, 1984) at $20^{\circ} \mathrm{C}$. The color of the isolates was determined visually.

\section{Identification of bacterial isolates}

Bacterial strains were identified based on the sequence similarity and phylogenetic analysis of $16 \mathrm{~S}$ rRNA gene sequences. Bacterial genomic DNA was extracted using the LaboPass tissue mini kit (Cosmogenetech, Korea). The 16S rRNA gene was PCR-amplified with two universal primers, 27F; 5'-AGA GTT TGA TCM TGG CTC AG-3' and 1492R; 5'-GGT TAC CTT GTT ACG ACT T-3', as described by Lane (1991). PCR was carried out using the method described by Lee et al. (2012). PCR products were purified using the LaboPass PCR purification kit (Cosmogenetech) and sequenced with the same primers used for amplification. The sequence of the 16S rRNA gene was compared with those of type strains available in the EzTaxon-e database (Kim et al., 2012) to find closely related species and to choose reference sequences for the phylogenetic analyses. Phylogenetic trees were reconstructed by the neighbor-joining method (Saitou and Nei, 1987) based on the distance matrix generated according to Kimura's two-parameter model (Kimura, 1980) and using phydit ver. 3.2 (http://plaza.snu.ac.kr/ jchun/phydit/). The confidence level of the tree topology was evaluated by bootstrap analysis using 1,000 sequence replications. The species affiliation of a bacterial isolate was determined when the isolate formed a monophyletic group with the reference species and based on a $98.65 \%$ or higher similarity (Kim et al., 2014). The sequences were submitted to NCBI GenBank under the accession numbers KJ475136-KJ475197 and KF977035.

\section{Results}

\section{Phylogenetic identification of the isolates}

Sixty-three isolates, affiliated with Actinobacteria, Bacteroidetes, 
Table 2. Taxonomic assignments and physiology of the bacterial isolates.

\begin{tabular}{|c|c|c|c|c|c|c|c|c|c|c|c|}
\hline \multirow{2}{*}{ Species name } & \multirow{2}{*}{$\begin{array}{l}\text { Similarity } \\
(\%)\end{array}$} & \multirow{2}{*}{$\begin{array}{l}\text { Temperature } \\
\text { range }\left({ }^{\circ} \mathrm{C}\right)\end{array}$} & \multicolumn{2}{|c|}{ Protease* } & \multicolumn{2}{|c|}{ Lipase* } & \multirow{2}{*}{$\begin{array}{c}\text { EPS } \\
\text { production }\end{array}$} & \multirow{2}{*}{$\begin{array}{c}\text { Pigment } \\
\text { characteristics }\end{array}$} & \multirow{2}{*}{$\begin{array}{l}\text { Sample } \\
\text { ID }\end{array}$} & \multirow{2}{*}{$\begin{array}{l}\text { PAMC } \\
\text { No. }\end{array}$} & \multirow{2}{*}{ Accession no. } \\
\hline & & & $10^{\circ} \mathrm{C}$ & $20^{\circ} \mathrm{C}$ & $10^{\circ} \mathrm{C}$ & $20^{\circ} \mathrm{C}$ & & & & & \\
\hline \multicolumn{12}{|l|}{ Actinobacteria } \\
\hline $\begin{array}{l}\text { Cryobacterium } \\
\text { psychrotolerans }\end{array}$ & 99.3 & $10-15$ & 3 & 2 & 0 & 0 & No & $\begin{array}{l}\text { Yellowish } \\
\text { cream }\end{array}$ & Sed3 & 27129 & KJ475137 \\
\hline $\begin{array}{l}\text { Marisediminicola } \\
\text { antarctica }\end{array}$ & 100.0 & $4-30$ & 0 & 0 & 0 & 0 & No & Apricot & Sed3 & 27228 & KJ475136 \\
\hline \multicolumn{12}{|l|}{ Bacteroidetes } \\
\hline Algibacter sp. & 97.2 & $4-15$ & 0 & 0 & 0 & 0 & No & Yellow & Sed1 & 27237 & KJ475138 \\
\hline Flavobacteriaceae sp. & 95.9 & $4-30$ & 0 & 0 & 2 & 2 & No & Yellow & Sed 1 & 27105 & KJ475139 \\
\hline Flavobacterium gelidilacus & 100.0 & $10-37$ & 2 & 2 & 2 & 3 & No & Yellow & Sed3 & 27103 & KJ475144 \\
\hline Flavobacterium gelidilacus & 99.6 & $4-25$ & 0 & 0 & 0 & 0 & Yes & Yellow & Sed3 & 27227 & KJ475154 \\
\hline Flavobacterium sp. & 99.4 & $10-30$ & 4 & 1 & 0 & 1 & No & Yellow & Sed3 & 27098 & KJ475140 \\
\hline Flavobacterium sp. & 98.9 & $4-15$ & 0 & 2 & 0 & 0 & No & Reddish & Sed3 & 27099 & KJ475141 \\
\hline Flavobacterium sp. & 99.2 & $10-15$ & 3 & 0 & 0 & 0 & Yes & Yellow & Sed3 & 27101 & KJ475142 \\
\hline Flavobacterium sp. & 99.0 & $10-20$ & 3 & 1 & 0 & 0 & Yes & Yellow & Sed3 & 27102 & KJ475143 \\
\hline Flavobacterium sp. & 99.1 & $4-30$ & 3 & 3 & 2 & 2 & No & Yellow & Sed3 & 27115 & KJ475145 \\
\hline Flavobacterium sp. & 99.1 & $4-30$ & 4 & 3 & 0 & 0 & No & Yellow & Sed3 & 27122 & KJ475146 \\
\hline Flavobacterium sp. & 99.1 & $4-20$ & 3 & 0 & 0 & 0 & No & Yellow & Sed3 & 27123 & KJ475147 \\
\hline Flavobacterium sp. & 99.1 & $4-20$ & 3 & 0 & 0 & 0 & Yes & Yellow & Sed3 & 27124 & KJ475148 \\
\hline Flavobacterium sp. & 99.1 & $10-20$ & 4 & 2 & 0 & 0 & No & Yellow & Sed3 & 27125 & KJ475149 \\
\hline Flavobacterium sp. & 99.2 & $4-20$ & 3 & 0 & 0 & 0 & No & Yellow & Sed3 & 27131 & KJ475150 \\
\hline Flavobacterium sp. & 99.1 & $4-20$ & 4 & 3 & 0 & 0 & Yes & Yellow & Sed3 & 27133 & KJ475151 \\
\hline Flavobacterium sp. & 99.2 & $4-20$ & 4 & 3 & 0 & 0 & No & Yellow & Sed3 & 27134 & KJ475152 \\
\hline Flavobacterium sp. & 99.1 & $4-20$ & 4 & 2 & 0 & 0 & Yes & Yellow & Sed3 & 27207 & KJ475153 \\
\hline Lacinutrix sp. & 97.5 & $4-10$ & 0 & 0 & 0 & 0 & No & Yellow & Sed 1 & 27137 & KF977035 \\
\hline Polaribacter sp. & 97.9 & $10-30$ & 0 & 0 & 0 & 0 & Yes & Yellow & Sed 1 & 27095 & KJ475155 \\
\hline Polaribacter sp. & 97.9 & $4-30$ & 0 & 0 & 2 & 2 & Yes & Yellow & Sed 1 & 27096 & KJ475156 \\
\hline Polaribacter sp. & 98.1 & $10-15$ & 1 & 0 & 0 & 0 & Yes & Reddish & Sed3 & 27100 & KJ475157 \\
\hline $\begin{array}{l}\text { Psychroserpens } \\
\text { damuponensis }\end{array}$ & 99.2 & $4-30$ & 0 & 0 & 0 & 0 & Yes & Yellow & Sed2 & 27240 & KJ475165 \\
\hline Psychroserpens sp. & 97.6 & $10-20$ & 0 & 0 & 0 & 0 & No & Reddish & Sed 1 & 27104 & KJ475158 \\
\hline Psychroserpens sp. & 97.8 & $4-30$ & 0 & 0 & 1 & 1 & Yes & Reddish & Sed 1 & 27106 & KJ475159 \\
\hline Psychroserpens sp. & 97.0 & 10 & 0 & 0 & 0 & 0 & No & $\begin{array}{l}\text { Greenish } \\
\text { Yellow }\end{array}$ & Sed3 & 27130 & KJ475160 \\
\hline Psychroserpens sp. & 97.3 & $4-20$ & 4 & 2 & 0 & 0 & Yes & Yellow & Sed 1 & 27206 & KJ475161 \\
\hline Psychroserpens sp. & 97.7 & $10-15$ & 3 & 3 & 0 & 0 & No & Reddish & Sed 1 & 27216 & KJ475162 \\
\hline Psychroserpens sp. & 97.1 & $10-15$ & 0 & 0 & 0 & 0 & No & Yellow & Sed 1 & 27220 & KJ475163 \\
\hline Psychroserpens sp. & 97.8 & $4-30$ & 0 & 0 & 0 & 0 & No & Reddish & Sed 1 & 27238 & KJ475164 \\
\hline Winogradskyella sp. & 98.5 & $4-30$ & 0 & 0 & 1 & 2 & Yes & Apricot & Sed 1 & 27097 & KJ475166 \\
\hline Winogradskyella sp. & 98.5 & $4-30$ & 0 & 0 & 2 & 1 & Yes & Apricot & Sed 1 & 27107 & KJ475167 \\
\hline Winogradskyella sp. & 98.5 & $10-30$ & 0 & 0 & 0 & 0 & Yes & Reddish & Sed 1 & 27217 & KJ475171 \\
\hline Winogradskyella sp. & 98.6 & $10-15$ & 0 & 0 & 0 & 0 & No & Reddish & Sed 1 & 27221 & KJ475172 \\
\hline Winogradskyella sp. & 97.0 & $10-20$ & 3 & 1 & 0 & 0 & No & Yellow & Sed3 & 27136 & KJ475168 \\
\hline Winogradskyella sp. & 97.1 & $10-15$ & 0 & 0 & 0 & 0 & No & Yellow & Sed3 & 27139 & KJ475169 \\
\hline Winogradskyella sp. & 97.0 & $10-37$ & 0 & 0 & 0 & 0 & Yes & Yellow & Sed3 & 27140 & KJ475170 \\
\hline \multicolumn{12}{|l|}{ Alphaproteobacteria } \\
\hline Loktanella salsilacus & 99.9 & $4-30$ & 3 & 0 & 0 & 0 & Yes & Beige & Sed3 & 27121 & KJ475175 \\
\hline Loktanella salsilacus & 100.0 & $4-30$ & 0 & 0 & 0 & 0 & No & Beige & Sed3 & 27229 & KJ475181 \\
\hline
\end{tabular}


122 Lee et al.

Table 2. continued

\begin{tabular}{|c|c|c|c|c|c|c|c|c|c|c|c|}
\hline \multirow{2}{*}{ Species name } & \multirow{2}{*}{$\begin{array}{l}\text { Similarity } \\
(\%)\end{array}$} & \multirow{2}{*}{$\begin{array}{c}\text { Temperature } \\
\text { range }\left({ }^{\circ} \mathrm{C}\right)\end{array}$} & \multicolumn{2}{|c|}{ Protease* } & \multicolumn{2}{|c|}{ Lipase* } & \multirow{2}{*}{$\begin{array}{c}\text { EPS } \\
\text { production }\end{array}$} & \multirow{2}{*}{$\begin{array}{c}\text { Pigment } \\
\text { characteristics }\end{array}$} & \multirow{2}{*}{$\begin{array}{c}\text { Sample } \\
\text { ID }\end{array}$} & \multirow{2}{*}{$\begin{array}{l}\text { PAMC } \\
\text { No. }\end{array}$} & \multirow{2}{*}{ Accession no. } \\
\hline & & & $10^{\circ} \mathrm{C}$ & $20^{\circ} \mathrm{C}$ & $10^{\circ} \mathrm{C}$ & $20^{\circ} \mathrm{C}$ & & & & & \\
\hline Loktanella sp. & 95.7 & $4-30$ & 0 & 0 & 1 & 0 & Yes & Beige & Sed 1 & 27117 & KJ475173 \\
\hline Loktanella sp. & 95.7 & $4-30$ & 0 & 0 & 1 & 0 & Yes & Beige & Sed 1 & 27118 & KJ475174 \\
\hline Loktanella sp. & 97.0 & 10 & 0 & 0 & 0 & 0 & No & Beige & Sed 1 & 27126 & KJ475176 \\
\hline Loktanella sp. & 97.0 & $4-20$ & 3 & 3 & 0 & 0 & No & Beige & Sed3 & 27132 & KJ475177 \\
\hline Loktanella sp. & 96.7 & $4-20$ & 4 & 2 & 0 & 0 & No & Cream & Sed3 & 27135 & KJ475178 \\
\hline Loktanella sp. & 96.8 & $10-15$ & 0 & 0 & 0 & 0 & No & Beige & Sed 1 & 27138 & KJ475179 \\
\hline Loktanella sp. & 96.4 & $10-15$ & 3 & 2 & 0 & 0 & No & Beige & Sed 1 & 27223 & KJ475180 \\
\hline Loktanella sp. & 97.1 & $10-25$ & 0 & 0 & 0 & 0 & No & Beige & Sed3 & 27241 & KJ475182 \\
\hline $\begin{array}{l}\text { Octadecabacter } \\
\text { antarcticus }\end{array}$ & 99.9 & $10-25$ & 0 & 0 & 0 & 0 & No & Beige & Sed 1 & 27224 & KJ475183 \\
\hline $\begin{array}{l}\text { Octadecabacter } \\
\text { antarcticus }\end{array}$ & 99.9 & $10-25$ & 0 & 0 & 0 & 0 & No & Beige & Sed 1 & 27225 & KJ475184 \\
\hline Roseovarius sp. & 97.0 & $10-20$ & 0 & 0 & 0 & 0 & No & Beige & Sed3 & 27236 & KJ475185 \\
\hline Sulfitobacter litoralis & 100.0 & $4-30$ & 2 & 0 & 0 & 0 & No & Beige & Sed2 & 27120 & KJ475187 \\
\hline Sulfitobacter litoralis & 99.6 & $4-30$ & 2 & 2 & 0 & 2 & No & Cream & Sed2 & 27109 & KJ475186 \\
\hline Sulfitobacter sp. & 98.1 & 10 & 0 & 0 & 0 & 0 & No & Beige & Sed 1 & 27222 & KJ475188 \\
\hline Sulfitobacter sp. & 98.1 & $10-15$ & 0 & 0 & 0 & 0 & No & Beige & Sed 1 & 27232 & KJ475189 \\
\hline \multicolumn{12}{|l|}{ Gammaproteobacteria } \\
\hline Psychrobacter luti & 99.8 & $4-30$ & 4 & 3 & 2 & 1 & Yes & Cream & Sed3 & 27116 & KJ475194 \\
\hline Psychrobacter luti & 100.0 & $4-30$ & 2 & 2 & 0 & 0 & No & Beige & Sed2 & 27119 & KJ475195 \\
\hline Psychrobacter nivimaris & 99.9 & $4-30$ & 0 & 1 & 2 & 0 & No & Cream & Sed2 & 27108 & KJ475190 \\
\hline Psychrobacter nivimaris & 99.9 & $4-30$ & 0 & 0 & 1 & 2 & No & Cream & Sed2 & 27110 & KJ475191 \\
\hline Psychrobacter nivimaris & 99.8 & $4-30$ & 0 & 0 & 1 & 2 & No & Cream & Sed2 & 27111 & KJ475192 \\
\hline Psychrobacter nivimaris & 99.9 & $4-30$ & 1 & 0 & 1 & 1 & No & Cream & Sed2 & 27112 & KJ475193 \\
\hline Psychrobacter submarinus & 99.9 & $10-30$ & 0 & 0 & 0 & 0 & No & Cream & Sed2 & 27239 & KJ475196 \\
\hline Shewanella gelidimarina & 99.7 & $4-10$ & 0 & 0 & 0 & 0 & No & Apricot & Sed1 & 27094 & KJ475197 \\
\hline
\end{tabular}

* The scores (from 1 to 4 ) represent the degree of production, with a higher number implying better production of protease and lipase

Alphaproteobacteria, and Gammaproteobacteria, were obtained from three sediment samples (Table 2 and Fig. 4). Two of the isolates belonged to the phylum Actinobacteria, represented by the genera Cryobacterium, and Marisediminicola; 36 isolates belonged to the phylum Bacteroidetes, represented by the genera Algibacter (1 isolate), Flavobacterium (15 isolates), Lacinutrix (1 isolate), Polaribacter (3 isolates), Psychroserpens (8 isolates), Winogradskyella (7 isolates), and the unidentified genus of family Flavobacteriaceae (1 isolate); 17 isolates of the class Alphaproteobacteria belonged to the genera Loktanella (10 isolates), Octadecabacter (2 isolates), Roseovarius (1 isolate), and Sulfitobacter (4 isolates); and 7 to the genus Psychrobacter and 1 member of the genus Shewanella of Gammaproteobacteria. Among these isolates, the largest groups in terms of the number of isolates recovered were those belonging to the genera Flavobacterium (15 isolates), Loktanella (10 isolates), Psychroserpens (8 isolates), and Winogradskyella (7 isolates), and Psychrobacter (7 isolates). Isolates affiliated with the genera Psychroserpens and
Sulfitobacter were obtained from all three sediments. The overall similarity of the isolates to known type strains ranged from $95.7 \%$ to $100 \%$ and 31 isolates $(49.2 \%$ over total strains) had $<98.65 \%$ 16S rRNA gene sequence similarity with the nearest type strains (Table 2).

\section{Physiological characteristics}

The growth temperature range of the 63 isolates and their production of extracellular enzymes, such as protease and lipase, and polymers were determined. Most of the isolates $(86 \%)$ produced apricot, beige, yellow, or red pigments readily recognizable with the unaided eye (Table 2). As the temperature increased from $4^{\circ} \mathrm{C}$ to $10^{\circ} \mathrm{C}$, the number of growing strains increased from 39 to 63 and then gradually decreased from $15^{\circ} \mathrm{C}$ (Fig. 1). Most of the isolates grew well between $10^{\circ} \mathrm{C}$ and $15^{\circ} \mathrm{C}$ but only three strains could grow at $37^{\circ} \mathrm{C}$ (Fig. 1).

Extracellular protease activities were detected in 29 isolates, belonging to the genera Cryobacterium, Flavobacterium, Polaribacter, Psychroserpens, Winogradskyella, Loktanella, 
Sulfitobacter, and Psychrobacter (Table 2). Strains belonging to the genera Flavobacterium (45\%), Psychrobacter (19\%), and Loktanella (13\%) accounted for a large proportion of the extracellular protease producers (Fig. 2A). Proteolysis at $10^{\circ} \mathrm{C}$ and $20^{\circ} \mathrm{C}$ was detected in 27 and 21 isolates, respectively (Table 2). Nineteen isolates showed extracellular protease activities both at $10^{\circ} \mathrm{C}$ and $20^{\circ} \mathrm{C}$ and higher extracellular protease activity was observed at $10^{\circ} \mathrm{C}$ than $20^{\circ} \mathrm{C}$. In particular, 21 isolates, belonging to the phylotypes Cryobacterium psychrotolerans, Flavobacterium sp., Psychroserpens sp., Winogradskyella sp., Loktanella salsilacus, Loktanella sp., and Psychrobacter luti (Table 2 and Fig. 4), had high extracellular protease activity (score $3 \geq$ ) at $10^{\circ} \mathrm{C}$ (Fig. 3A).

Sixteen isolates, belonging to the genera Flavobacterium, Polaribacter, Psychroserpens, Winogradskyella, Loktanella, Sulfitobacter, Psychrobacter, and unidentified genus of the family Flavobacteriaceae, had extracellular lipase activity, with strains of the genera Psychrobacter (31\%), Flavobacterium (19\%), Loktanella (13\%), and Winogradskyella (13\%) accounting for a large proportion of the extracellular lipase producers (Fig. 2B). Fourteen isolates exhibited enzyme activity at $10^{\circ} \mathrm{C}$ and 13 isolates exhibited enzyme activity at $20^{\circ} \mathrm{C}$ (Table 2). Among the 11 isolates with extracellular lipase activity at both $10^{\circ} \mathrm{C}$ and $20^{\circ} \mathrm{C}$, score-based enzyme activity was higher at the higher temperature (Fig. 3B). There were no isolates that had an extracellular lipase activity of score 4 and only one strain, PAMC 27103, had an extracellular lipase activity of score 3 at $20^{\circ} \mathrm{C}$. This strain had $100 \%$ similarity with Flavobacterium gelidilacus (Table 2 and Fig. 4).

The 20 isolates that produced exopolysaccharides at $20^{\circ} \mathrm{C}$ were affiliated with the genera Flavobacterium, Polaribacter, Psychroserpens, Winogradskyella, Loktanella, and Psychrobacter (Table 2). Among them, strains belonging to the genera Flavobacterium (30\%) were the most abundant followed by

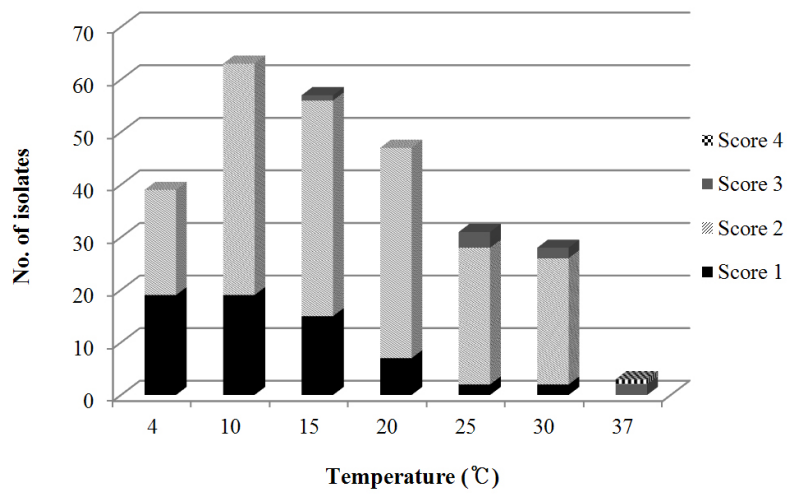

Fig. 1. Effect of temperature on bacterial growth. The scores (from 1 to 4) represent the degree of growth, with a higher number implying better growth.
Winogradskyella (20\%), Loktanella (15\%), Polaribacter (15\%), and Psychroserpens (15\%) (Fig. 2C). Approximately 43 isolates $(70 \%)$ produced at least one extracellular enzyme or exopolysaccharide, and the isolate, PAMC 27116, with $99.2 \%$ similarity to Psychrobacter luti, produced three of them (Table 2).

\section{Discussion}

In the sediments from Ross Sea, Antarctica, both the spatial distribution of the organic matter composition and bacterial densities have been reported (Fabiano and Danovaro, 1998; Fabiano and Pusceddu, 1998; Pusceddu et al., 2000; Baldi et al., 2010). The bacterial community of Ross Sea sediments, as determined by T-RFLP analysis, revealed the predominance of bacteria belonging to Gammaproteobacteria, Deltaproteobacteria, Bacteroidetes, and Acidobacteria (Baldi et al., 2010). To the best of our knowledge, this is the first report on the diversity and physiological characteristics of culturable bacteria in Ross Sea sediments. The culturable bacteria present in the samples

(A)

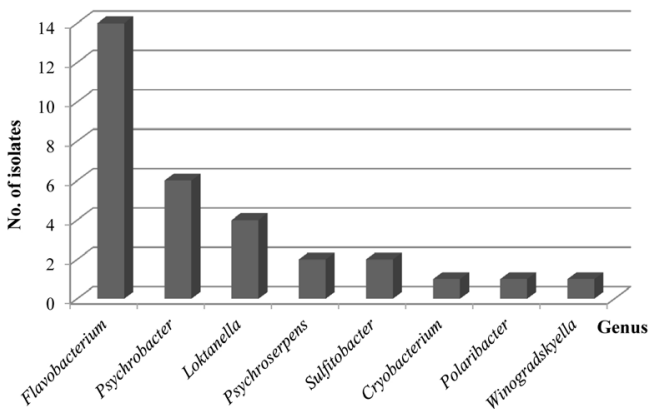

(B)

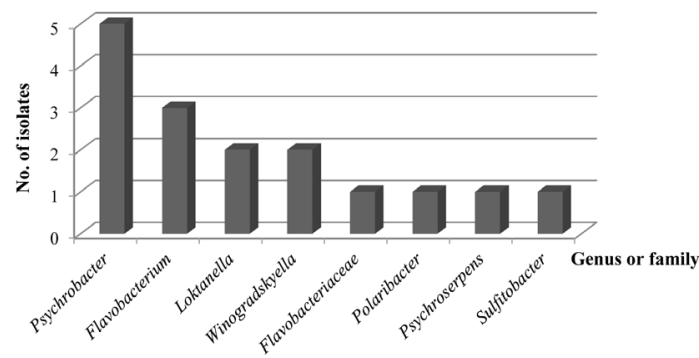

(C)

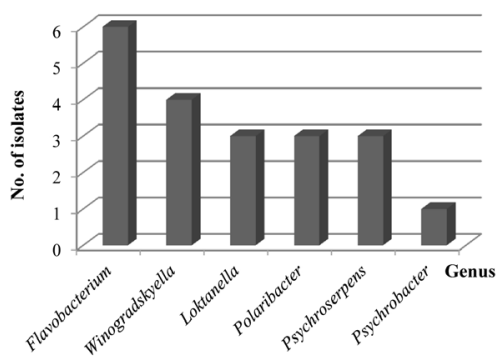

Fig. 2. Abundance of isolates, according to genus or family, that produce extracellular protease (A), lipase (B), and exopolysaccharides (C). 
were affiliated with 16 genera (Table 2) and many of them (70\%) produced extracellular protease, lipase, and/or exopolysaccharides. Most of the organic matter in benthic communities is produced as high-molecular-weight polymeric compounds, which before they can be incorporated into microbial cells must be degraded by a series of extracellular hydrolytic enzymes (Yu et al., 2011). The finding in this study, that a large proportion of the isolates produced at least one type of extracellular enzymes, points to the significant roles played by benthic microorganisms in the biogeochemical cycles of Ross Sea sediments. In addition, analyses of temperaturedependent growth showed that the number of isolates capable of growing at $10^{\circ} \mathrm{C}$ was highest, indicating an adaption at the stable, low temperature of the bottom sediments in the Southern Ocean (Helmke and Weyland, 2004).

The predominance of the phylum Bacteroidetes is known in the previous studies of bacterial communities from marine sediments of Antarctica (Bowman and McCuaig, 2003; Baldi et

(A)

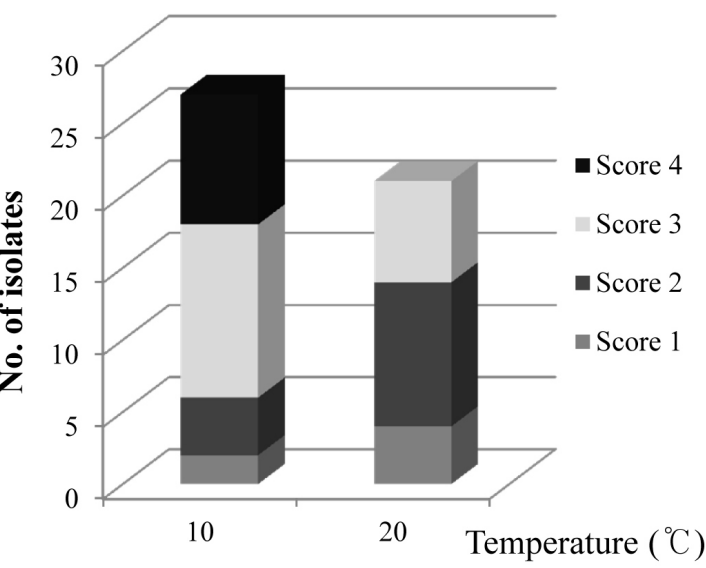

(B)

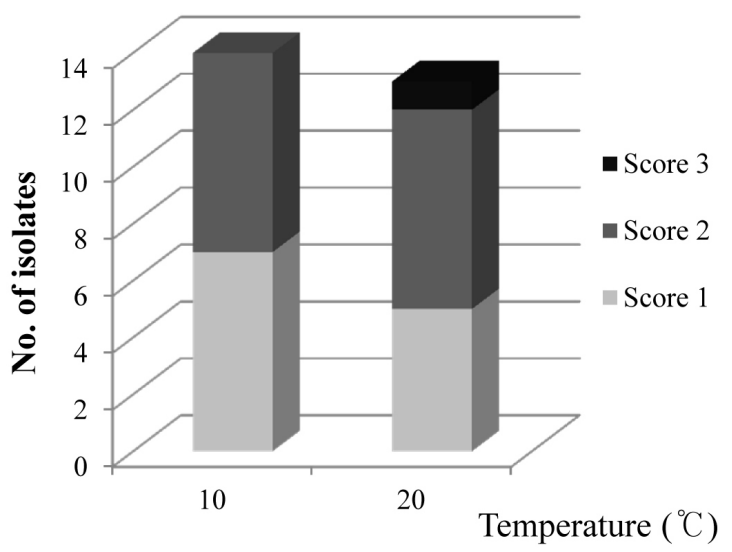

Fig. 3. Frequency of bacterial isolates with extracellular protease (A) and lipase (B) activities. The scores (from 1 to 4) represent the degree of production, with a higher number implying better production. al., 2010). In this study, 59\% of total recovered isolates belonged to the phylum Bacteroidetes. Among them, the large percentage $(67 \%, 29$ isolates out of 43$)$ of extracellularmaterial-producing strains were affiliated with the genera Flavobacterium, Polaribacter, Psychroserpens, Winogradskyella, and unidentified genus of the family Flavobacteriaceae and it is consistent with the well-established finding of biopolymer hydrolysis by this phylum (Kirchman, 2002). In addition, extracellular protease or lipase production by isolates assigned to the genera Cryobacterium, Loktanella, Psychrobacter, and Sulfitobacter, belonging to Actinobacteria, Alphaproteobacteria, and Gammaproteobacteria (Table 2), reflects the importance of these strains in the hydrolysis of organic constituents.

Twenty-one isolates, affiliated with the genera Flavobacterium, Polaribacter, Psychroserpens, Winogradskyella, Loktanella, Sulfitobacter, and Psychrobacter produced at least two extracellular proteases, lipases, and/or exopolysaccharides. Of these isolates, members of the genus Flavobacterium (33\%) clearly dominated. The strains of the genus Flavobacterium are known for their specialized roles in the uptake and degradation of the high-molecular-mass fraction of dissolved organic matter and in remineralization processes, both in freshwater and in marine ecosystems (McCammon and Bowman, 2000). They have been frequently reported in oligotrophic and eutrophic Antarctic freshwater, terrestrial samples, and marine sediments, suggesting their wide diffusion in Antarctica and their ecological roles in macromolecule hydrolysis (McCammon et al., 1998; McCammon and Bowman, 2000; Humphry et al., 2001; Van Trappen et al., 2003, 2005; Yi et al., 2005; Yi and Chun, 2006; Michaud et al., 2012).

Although culturable bacteria do not fully represent the bacterial communities of the environment, many candidate novel species with $<98.65 \%$ similarity to known strains, were recovered in this study. This result demonstrates that relatively simple cultivation methods can be used to isolate as-yetundescribed taxa and they can be used for expanding the knowledge on the unknown functions and physiologies of bacterial OTUs obtained by molecular techniques. In addition, our finding that culturable bacteria produce cold-active enzymes indicates that the isolated strains contribute to the hydrolysis of major organic constituents and are therefore involved in carbon and nitrogen cycling at the low temperature of sediments of Ross Sea, Antarctica.

\section{적요}

남극 로스해의 퇴적물로부터 배양을 통해 분리한 균주의 분류 및 생리학적 특성 분석을 수행하였다. 분리 세균 63 균주의 $16 \mathrm{~S}$ rRNA 유전자 염기서열을 이용한 계통분류학적 분석 결과, 이들 


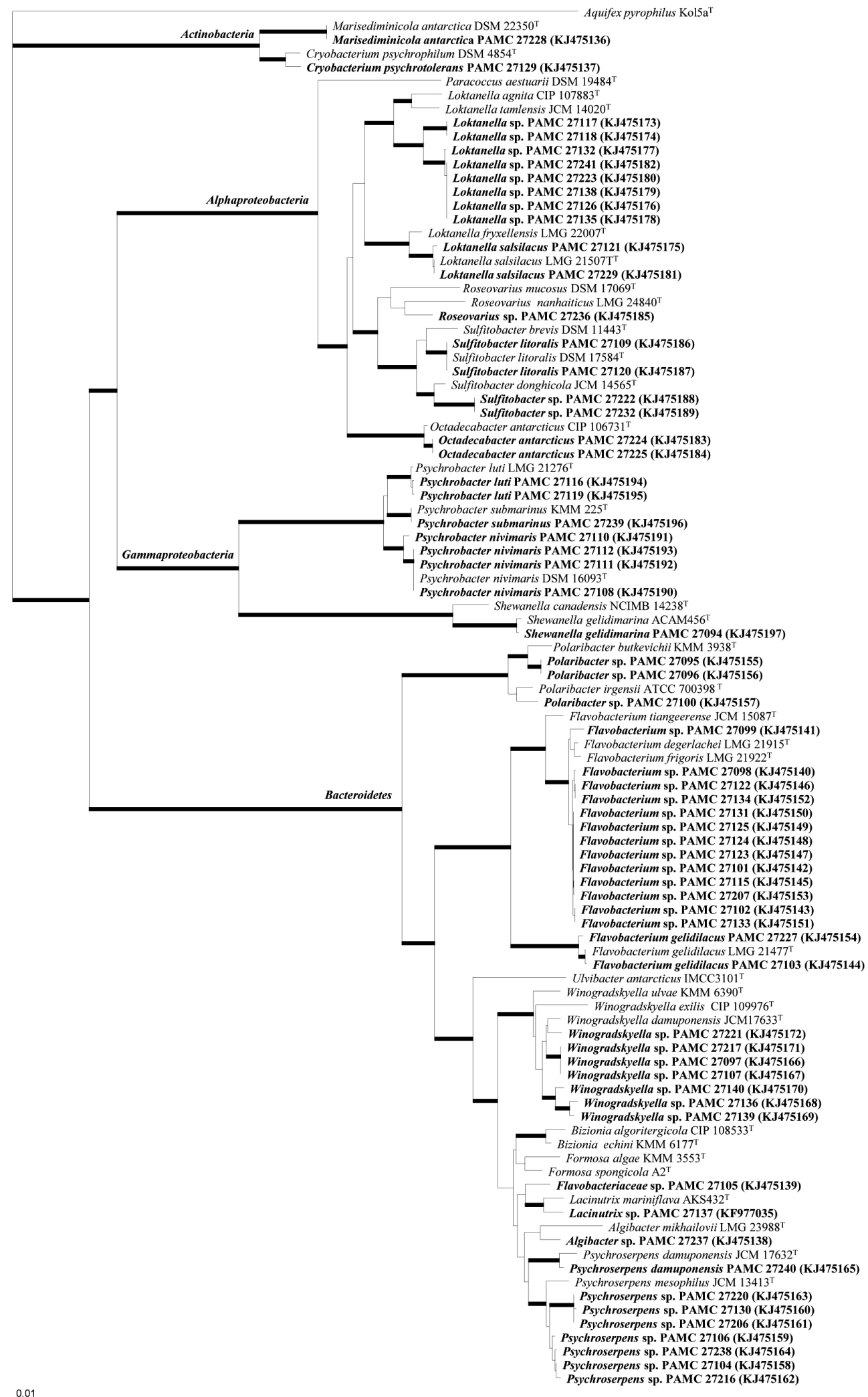

Fig. 4. Neighbor-joining tree of isolates with closely related reference species, based on the 16S rRNA gene sequences. Representative isolates for each phylotype are indicated by bold letters, and branches supported by high bootstrap values $(>70 \%)$ as thick lines. Bar, 1 nucleotide substitutions per 100 nucleotides. 
은 Actinobacteria, Bacteroidetes, Alphaproteobacteria 및 Gammaproteobacteria 내의 21개의 파일로타입(phylotypes)에 속하였다. $98.65 \%$ 염기서열 유사도를 기준으로, 약 $49 \%$ 의 균주 가 잠재적으로 신종 또는 신속 후보인 것으로 나타났다. 분리된 균주 중, 각각 $46 \%, 25 \%$ 및 $32 \%$ 의 균주가 세포외 단백질분해효 소, 지질분해효소 및 외부다당체 생성에 대한 활성을 나타냈다. 43 개의 균주는 최소 1 개의 세포외 분비 물질을 생산하였고, 이들 중 21 개 균주는 최소 2 개의 세포외 단백질분해효소, 지질분해효 소 또는/및 세포외다당체를 생성하였다. 이러한 결과는 남극 로스 해 퇴적물 내의 배양된 세균 군집이 해당 환경에서 탄소와 질소와 관련된 유기물질의 가수분해에 영향을 미치고 있다는 것을 시사 한다.

\section{Acknowledgements}

This research was supported by the Korea Polar Research Institute (Grant PM11030 and PE14080). We thank the captain Hyun-Yul Kim and crews of R/V ARAON for their support at sea.

\section{References}

Bai, Y., Yang, D., Wang, J., Xu, S., Wang, X., and An, L. 2006. Phylogenetic diversity of culturable bacteria from alpine permafrost in the Tianshan Mountains, Northwestern China. Res. Microbiol. 157, 741-751.

Baldi, F., Marchetto, D., Pini, F., Fani, R., Michaud, L., Lo Giudice, A., Berto, D., and Giani, M. 2010. Biochemical and microbial features of shallow marine sediments along the Terra Nova Bay (Ross Sea, Antarctica). Cont. Shelf Res. 30, 1614-1625.

Bowman, J.P. and McCuaig, R.D. 2003. Biodiversity, community structural shifts, and biogeography of prokaryotes within Antarctic continental shelf sediment. Appl. Environ. Microbiol. 69, 24632483.

Fabiano, M. and Danovaro, R. 1998. Enzymatic activity, bacterial distribution, and organic matter composition in sediments of the Ross Sea (Antarctica). Appl. Environ. Microbiol. 64, 3838-3845.

Fabiano, M. and Pusceddu, A. 1998. Total and hydrolizable particulate organic matter (carbohydrates, proteins and lipids) at a coastal station in Terra Nova Bay (Ross Sea, Antarctica). Polar Biol. 19, 125 -132 .

Gerday, C., Aittaleb, M., Bentahir, M., Chessa, J.P., Claverie, P., Collins, T., D'Amico, S., Dumont, J., Garsoux, G., Georlette, D., and et al. 2000. Cold-adapted enzymes: from fundamentals to biotechnology. Trends Biotechnol. 18, 103-107.

Groudieva, T., Kambourova, M., Yusef, H., Royter, M., Grote, R., Trinks, H., and Antranikian, G. 2004. Diversity and cold-active hydrolytic enzymes of culturable bacteria associated with arctic sea ice, Spitzbergen. Extremophiles 8, 475-488.

Helmke, E. and Weyland, H. 2004. Psychrophilic versus psychrotolerant bacteria-occurrence and significance in polar and temperate marine habitats. Cell. Mol. Biol. 50, 553-561.

Humphry, D.R., George, A., Black, G.W., and Cummings, S.P. 2001. Flavobacterium frigidarium sp. nov., an aerobic, psychrophilic, xylanolytic and laminarinolytic bacterium from Antarctica. Int. $J$.
Syst. Evol. Microbiol. 51, 1235-1243.

Jiang, H.L., Tay, S.T., Maszenan, A.M., and Tay, J.H. 2006. Physiological traits of bacterial strains isolated from phenol-degrading aerobic granules. FEMS Microbiol. Ecol. 57, 182-191.

Kim, O.S., Cho, Y.J., Lee, K., Yoon, S.H., Kim, M., Na, H., Park, S.C., Jeon, Y.S., Lee, J.H., Yi, H., and et al. 2012. Introducing EzTaxon-e: a prokaryotic $16 \mathrm{~S}$ rRNA gene sequence database with phylotypes that represent uncultured species. Int. J. Syst. Evol. Microbiol. 62, 716-721.

Kim, M., Oh, H.S., Park, S.C., and Chun, J. 2014. Towards a taxonomic coherence between average nucleotide identity and 16S rRNA gene sequence similarity for species demarcation of prokaryotes. Int. $J$. Syst. Evol. Microbiol. 64, 346-351.

Kim, S.J. and Yim, J.H. 2007. Cryoprotective properties of exopolysaccharide (P-21653) produced by the Antarctic bacterium, Pseudoalteromonas arctica KOPRI 21653. J. Microbiol. 45, 510 514.

Kimura, M. 1980. A simple method for estimating evolutionary rates of base substitutions through comparative studies of nucleotide sequences. J. Mol. Evol. 16, 111-120.

Kirchman, D.L. 2002. The ecology of Cytophaga-Flavobacteria in aquatic environments. FEMS Microbiol. Ecol. 39, 91-100.

Lane, D.J. 1991. 16S/23S rRNA sequencing, pp. 115-175. In Stackebrandt, E. and Goodfellow, M. (eds.), Nucleic Acid Techniques in Bacterial Systematics. John Wiley \& Sons Press, New York, N.Y., USA.

Lee, Y., Kim, G., Jung, Y.J., Choe, C.D., Yim, J., Lee, H., and Hong, S. 2012. Polar and alpine microbial collection (PAMC): a culture collection dedicated to polar and alpine microorganisms. Polar Biol. 35, 1433-1438.

Li, H., Yu, Y., Luo, W., Zeng, Y., and Chen, B. 2009. Bacterial diversity in surface sediments from the Pacific Arctic Ocean. Extremophiles 13, 233-246.

Macura, D. and Townsley, P.M. 1984. Scandinavian ropy milk-identification and characterization of endogenous ropy lactic streptococci and their extracellular excretion. J. Dairy Sci. 67, 735744.

McCammon, S.A., Innes, B.H., Bowman, J.P., Franzmann, P.D., Dobson, S.J., Holloway, P.E., Skerratt, J.H., Nichols, P.D., and Rankin, L.M. 1998. Flavobacterium hibernum sp. nov., a lactose-utilizing bacterium from a freshwater Antarctic lake. Int. J. Syst. Evol. Microbiol. 48, 1405-1412.

McCammon, S.A. and Bowman, J.P. 2000. Taxonomy of Antarctic Flavobacterium species: Description of Flavobacterium gillisiae sp. nov., Flavobacterium tegetincola sp. nov., and Flavobacterium xanthum sp. nov., nom. rev. and reclassification of [Flavobacterium] salegens as Salegentibacter salegens gen. nov., comb. nov. Int. J. Syst. Evol. Microbiol. 50, 1055-1063.

Michaud, L., Caruso, C., Mangano, S., Interdonato, F., Bruni, V., and Lo Giudice, A. 2012. Predominance of Flavobacterium, Pseudomonas, and Polaromonas within the prokaryotic community of freshwater shallow lakes in the northern Victoria Land, East Antarctica. FEMS Microbiol. Ecol. 82, 391-404.

Polymenakou, P., Bertilsson, S., Tselepides, A., and Stephanou, E. 2005. Bacterial community composition in different sediments from the Eastern Mediterranean Sea: a comparison of four $16 \mathrm{~S}$ ribosomal DNA clone libraries. Microb. Ecol. 50, 447-462.

Pusceddu, A., Dell'Anno, A., and Fabiano, M. 2000. Organic matter composition in coastal sediments at Terra Nova Bay (Ross Sea) 
during summer 1995. Polar Biol. 23, 288-293.

Ravenschlag, K., Sahm, K., and Amann, R. 2001. Quantitative molecular analysis of the microbial community in marine Arctic sediments (Svalbard). Appl. Environ. Microbiol. 67, 387-395.

Russell, N. 1998. Molecular adaptations in psychrophilic bacteria: potential for biotechnological applications, p. 1-21. In Antranikian, G. (ed.), Biotechnology of extremophiles, Springer Berlin Heidelberg, Germany.

Saitou, N. and Nei, M. 1987. The neighbor-joining method: a new method for reconstructing phylogenetic trees. Mol. Biol. Evol. 4, 406-425.

Selbmann, L., Onofri, S., Fenice, M., Federici, F., and Petruccioli, M. 2002. Production and structural characterization of the exopolysaccharide of the Antarctic fungus Phoma herbarum CCFEE 5080. Res. Microbiol. 153, 585-592.

Staley, J.T. and Herwig, R.P. 1993. Degradation of particulate organic material in the Antarctic, pp. 241-264. In Friedmann, E.I. (ed.), Antarctic Microbiology. Wiley-Liss Inc., New York, N.Y., USA.

Van Trappen, S., Mergaert, J., and Swings, J. 2003. Flavobacterium gelidilacus sp. nov., isolated from microbial mats in Antarctic lakes. Int. J. Syst. Evol. Microbiol. 53, 1241-1245.

Van Trappen, S., Vandecandelaere, I., Mergaert, J., and Swings, J. 2005. Flavobacterium fryxellicola sp. nov. and Flavobacterium psychrolimnae sp. nov., novel psychrophilic bacteria isolated from microbial mats in Antarctic lakes. Int. J. Syst. Evol. Microbiol. 55, 769-772.

Vazquez, S.C., Coria, S.H., and Mac Cormack, W.P. 2004. Extracellular proteases from eight psychrotolerant Antarctic strains. Microbiol. Res. 159, 157-166.

Webster, G., John Parkes, R., Cragg, B.A., Newbery, C.J., Weightman, A.J., and Fry, J.C. 2006. Prokaryotic community composition and biogeochemical processes in deep subseafloor sediments from the Peru Margin. FEMS Microbiol. Ecol. 58, 65-85.

Whitman, W.B., Coleman, D.C., and Wiebe, W.J. 1998. Prokaryotes: The unseen majority. Proc. Natl. Acad. Sci. USA 95, 6578-6583.

Yi, H. and Chun, J. 2006. Flavobacterium weaverense sp. nov. and Flavobacterium segetis sp. nov., novel psychrophiles isolated from the Antarctic. Int. J. Syst. Evol. Microbiol. 56, 1239-1244.

Yi, H., Oh, H.M., Lee, J.H., Kim, S.J., and Chun, J. 2005. Flavobacterium antarcticum sp. nov., a novel psychrotolerant bacterium isolated from the Antarctic. Int. J. Syst. Evol. Microbiol. 55, 637-641.

Yu, Y., Li, H.R., Zeng, Y.X., and Chen, B. 2011. Bacterial diversity and bioprospecting for cold-active hydrolytic enzymes from culturable bacteria associated with sediment from Nella Fjord, Eastern Antarctica. Mar. Drugs 9, 184-195. 